\title{
AKULTURASI ISLAM JAWA DALAM TRADISI NYUMBANG MANTU (Studi Kasus Masyarakat Wates Semarang dengan Pendekatan Antropologi Dakwah)
}

\author{
Safrodin \\ Fakultas Dakwah dan Komunikasi UIN Walisongo Semarang \\ Email: safrodinhalimi@gmail.com
}

\begin{abstract}
Abstrak
This study aims to explain one of the embodiment of acculturation of Islamic and Javanese culture in the tradition of mantu and nyumbang mantu on Javanese society at Wates Semarang with anthropological perspective. Mantu in the tradition of the Javanese society includes mantu khitanan and mantu ngantenan. It has an important meaning in the eyes of the people. In addition to the cultural demands, in it also has the meaning of religion, custom and meaning of prestige for them, so that as much as possible they will hold a mantu though must with gotong royong. Gotong royong has long been formed in the tradition of nyumbang mantu. This tradition of nyumbang mantu is a manifestation of brotherhood and solidarity in society, as well as a social obligation accompanied by other expectations such as social prestige, social dignity and blessings. The nyumbang mantu is also a manifestation of the ta'āwun principle in a society that has been institutionalized in tradition and culture. On the other hand, the transformation of mantu from simple slametan to walimah, which is accompanied by religious teachings [pengajian] of mantenan and religious entertainment, especially in santri society, is actually a form of acculturation of Java and Islam. This acculturation occurs as a process of strengthening to the Islamic values in society. Because, the certain values that society believes will only survive when it grows and develops into a culture in society.
\end{abstract}

Penelitian ini bertujuan untuk menjelaskan salah satu perwujudan akulturasi budaya Islam dan Jawa dalam tradisi mantu dan nyumbang mantu pada masyarakat Jawa di Wates Semarang dengan perspektif antropologi. Mantu dalam tradisi masyarakat Jawa termasuk mantu khitanan dan mantu ngantenan. Ini memiliki arti penting di mata rakyat. Selain tuntutan budaya, di dalamnya juga memiliki makna agama, adat dan makna prestise bagi mereka, sehingga semaksimal mungkin mereka akan menggandeng mantu meski harus dengan gotong royong. Gotong royong telah lama terbentuk dalam tradisi nyumbang mantu. Tradisi nyumbang mantu ini merupakan wujud persaudaraan dan solidaritas dalam masyarakat, sekaligus sebagai kewajiban sosial disertai dengan harapan lain seperti prestise sosial, martabat dan berkah sosial. Nyumbang mantu juga merupakan manifestasi dari prinsip ta'āwun dalam masyarakat yang telah dilembagakan dalam tradisi dan budaya. Di sisi lain, transformasi mantu dari slametan sederhana 
ke walīmah, yang disertai dengan ajaran agama [pengajian] mantenan dan hiburan religius, terutama di kalangan santri, sebenarnya adalah bentuk akulturasi Jawa dan Islam. Akulturasi ini terjadi sebagai proses penguatan nilai-nilai Islam di masyarakat. Sebab, nilai-nilai tertentu yang diyakini masyarakat hanya akan bertahan saat tumbuh dan berkembang menjadi budaya masyarakat

Kata Kunci : Akulturasi, Mantu, Nyumbang Mantu

\section{A. Pendahuluan}

Masyarakat Jawa sangat kental dengan tradisi gotong royong dengan beragam bentuknya. Semboyan "mangan ora mangan seng penting kumpul" adalah gambaran tegas yang menjelaskan makna filosofi kumpul (berkumpul atau komunalitas) sedemikian tinggi artinya bagi mereka mengalahkan segala-galanya. Sebab itu, banyak persoalan dan kebutuhan masyarakat diselesaikan secara bersama dan gotong royong, seperti bangun jalan, bangun kuburan, sambatan bangun rumah, dan gotong royong dalam hajatan mantu.

Masyarakat jawa mempunyai sejarah panjang dengan berbagai konsep yang beragam. Konsep tersebut diyakini dan dipahami sebagai nilai budaya yang selalu dilestarikan. Salah satu tradisi dan nilai yang ada di masyarakat Jawa adalah gotong royong dalam hajatan mantu. Fokus kajian dalam artikel ini terutama masyarakat Wates Ngaliyan Semarang. Masyarakat Wates termasuk dalam kategori masyarakat agraris yang mengandalkan mata pencarian dari hasil cocok tanam padi dan hasil perkebunan lainnya. Mereka mumpunyai lahan tanah untuk bercocok tanam sebagai aset utama yang mereka miliki dari peninggalan turun temurun nenek moyang mereka.

Konon, nenek moyang mereka adalah masyarakat tuan tanah yang memiliki berhektar-hektar lahan untuk bercocok tanam dan berkebun dalam memenuhi kebutuhan hidupnya. Mereka minimal memiliki tanah seluas 3 hektar. Bagi mereka, memiliki tiga hektar tanah seperti tidak memiliki tanah, karena jumlah luas tanah tersebut merupakan yang paling sedikit di antara mereka ${ }^{1}$. Kondisi demikian terjadi sejak zaman kemerdekaan hingga tahun 90-an. Namun, setelah era tahun 90-an hingga sekarang luas tanah yang mereka miliki semakin berkurang, lantaran sudah diwariskan kepada anak keturunannya dan sebagian lagi dijual untuk memenuhi kebutuhan hidupnya.

1 Pandangan ini disimpulkan dari hasil wawancara dengan Syamsi, 10 Juli 2016. 
Bagi sebagian besar masyarakat Wates, menjual tanah adalah solusi jitu untuk menyelesaikan sebagian persoalan dalam hidupnya baik persoalan primer maupun sekunder. Mereka tidak segan-segan menjual tanah sekedar untuk hajatan mantu maupun membangun rumah untuk anaknya yang sudah menikah. Karena, mereka meyakini bahwa kehormatan orang tua itu terletak pada tugas mereka melahirkan anak, membesarkan anak, menikahkannya dan membangunkan rumah untuknya. Tugas-tugas itu merupakan tugas yang sangat penting dan bernilai bagi mereka, sehingga agar tugas tersebut berjalan dengan sukses perlu gotong royong dalam pelaksanaannya, termasuk gotong royong dalam acara mantu.

Gotong royong dalam acara mantu di kalangan masyarakat Wates tersebut terwujud dalam bentuk budaya nyumbang mantu. Yang menarik dari fenomena ini adalah bahwa budaya nyumbang mantu mengalami perkembangan dari nyumbang secara apa adanya sebagai sodaqoh menjadi nyumbang mantu sebagai 'arisan' atau 'resiprositas' dalam istilah antropolgi. Sekalipun sebenarnya, bagi sebagian mereka, mengembalikan sumbangan yang pernah didapatkannya ketika punya gawe mantu, dirasa cukup berat karena memakan waktu puluhan tahun atau bahkan seumur hidup, namun tradisi nyumbang mantu tersebut tetap saja berjalan (established). Permasalahannya adalah bagaimanakah dan mengapakah tradisi nyumbang mantu di Wates sedemikian mapan, sekalipun oleh sebagian masyarakat dirasa cukup memberatkan.

\section{B. Nyumbang Mantu dalam Tradisi Masyarakat Wates}

Acara mantu dalam tradisi masyarakat Jawa Wates Ngaliyan Semarang adakalanya berbentuk 'mantu sunatan' [khitanan dalam tradisi Islam-Jawa sering disebut sunatan karena sangat dianjurkan dalam Islam], dan juga berupa 'mantu ngantenan'. Terma 'mantu' dianggap singkatan dari "sing dieman-eman metu", artinya bahwa pada acara mantu ini segala sesuatu yang selama itu dikumpulkan dan disimpan seperti harta benda simpanan, itu dikeluarkan untuk mensukseskan acara tersebut. Hal ini menunjukkan betapa penting arti mantu dalam pandangan masyarakat tersebut. Karenanya, mereka berusaha untuk menyelenggarakannya dengan sebaik-baiknya dan sekuat tenaga, sekalipun sebagian melakukannya harus dengan hutang atau bahkan menjual sebagain tanah, satu-satunya aset berharga yang mereka miliki. ${ }^{2}$ Laksana aib bagi mereka,

\footnotetext{
2 Hasil wawancara dengan Sopiah pada 23-7-2016.
} 
apabila mereka tidak dapat menyelenggarakan acara mantu untuk putraputrinya sebagaimana keluarga lain lakukan.

Signifikansi mantu tersebut di kalangan mereka telah menjadi tuntutan kultural. Karena, ada makna religi, adat maupun makna prestise sosial bagi mereka dalam penyelenggaraan mantu tersebut. Pada satu sisi, ngantenan (nikah) atau sunatan [khitan] dengan segala ritualnya merupakan tugas sakral dalam agama maupun adat. Karena dalam mantu terdapat syariat 'nikah' atau 'khitan' yang diperintahkan oleh agama. Nikah adalah bagian dari sunnah Nabi saw yang sangat dianjurkan bagi umatnya. Bahkan kesempurnaan keberagamaan seseorang juga ditentukan oleh masa setelah pernikahan terjadi, di samping fungsi untuk menjaga kehormatan moral dan kehormatan diri. ${ }^{3}$ Sedangkan 'khitan' merupakan syariat yang sangat dianjurkan bagi kaum muslim laki-laki agar terjaga kesuciannya dari najis kotoran kencing. Nabi saw. memerintahkan umatnya untuk berkhitan, karena hal itu membuat wajah orang yang dikhitan lebih cemerlang dan lebih menyenangkan. ${ }^{4}$ Syariat ini ditetapkan dalam Islam setelah sebelumnya dilaksanakan oleh Nabi Ibrahim as.

Pada sisi lain, dalam acara mantu juga terdapat makna prestise sosial bagi keluarga maupun masyarakat, yakni harapan seseorang untuk menjaga atau bahkan meningkatkan gengsi, wibawa atau kehormatan sosialnya di tengah-tengah masyarakatnya dengan berusaha untuk menyelenggarakan acara mantu itu secara lebih baik dan lebih meriah menurut pandangan mereka. Setidaknya bentuk mantu dengan segala pernak-perniknya menunjukkan eksistensi seseorang baik dalam relasi sosial maupun kekayaannya di tengah-tengah masyarakat.

Meminjam istilah Soekanto (1990), bahwa dalam realitas kehidupan petani Jawa Wates ini, mereka juga terbagi dalam beragam lapisan sosial yang bertingkat, di mana setiap lapisan akan mendapatkan penghargaan, status, dan pengakuan yang berbeda satu sama lain. Salah satu ukuran atau kriteria yang menentukan prestise sosial seseorang adalah kekayaan di samping kekuasaan dan ilmu. Hal ini berarti bahwa siapapun yang memiliki kekayaan paling banyak, maka akan termasuk pada lapisan atas. Kekayaan yang dimiliki seseorang akan terlihat secara nyata, salah satunya melalui simbol pola penyelenggaraan 'acara mantu'. Suatu kehormatan ini tidak terlepas dari ukuran kekuasaan atau kekayaan. Orang yang disegani dan dihormati oleh masyarakat akan mendapat tempat pada lapisan atas. ${ }^{5}$

3 Zakiyuddin Abdul Adzim al-Mundziri,, al-Targhib wa al-Targhib min al-Hadits alSyarif, (Beirut-Libanon, Dar al-Fikr, 2010), 11-13.

${ }^{4}$ Al-Imam Abu Daud, Sunan Abu Dawud, (Beirut-Libanon, Dar al-Fikr, t.t.), 5271.

5 Soerjono Soekanto, Pengantar Sosiologi, (Jakarta: Rajawali Press, 1990), 131-137. 
Menurut teori Radifield (1963), kondisi yang dihadapi masyarakat Wates yang mayoritas bermata pencaharian petani merupakan masyarakat petani desa yang berada di antara tarik menarik budaya desa murni dan budaya perkotaan. ${ }^{6}$ Gaya hidup mereka di antaranya mendambakan kekayaan dan gemar memamerkan kekayaan. ${ }^{7}$ Karena, prestise sosial yang memungkinkan didapatkan mereka salah satunya adalah melalui kekayaan yang secara simbolik dapat diekspresikan dalam tradisi mantu tersebut. Semakin seseorang mampu menyelenggarakan 'mantu' secara meriah, maka semakin tinggi prestise sosial yang mereka dapatkan.

Pada satu sisi, seseorang melalui acara mantu yang meriah dapat menunjukkan kemampuan dan eksistensi kekayaannya kepada masyarakat sekitarnya. Pada sisi lain, mantu yang dilakukan dapat menunjukkan relasi sosial, kelas sosial dan kedudukannya di antara masyarakat dengan menghadirkan para tamu undangan dari kalangan yang diakui memiliki tingkatan sosial yang tinggi, baik karena kekuasaan, kekayaan, atau ilmu pengetahuannya. Demikian sebaliknya, semakin tidak meriah mantu itu, maka semakin jelas kedudukan sosial seseorang atau semakin turun tingkat prestise sosialnya. Makna agama dan harapan itu dibingkai dalam sebuah tradisi atau adat yang disebut "mantu". Oleh karena itu, ketika suatu nilai dibingkai dalam sebuah tradisi masyarakat, maka muncullah kesadaran sosial bahwa mantu itu menjadi 'kewajiban sosial' bagi setiap orang dalam masyarakatnya.

Dengan demikian, dapat dipahami apabila -dalam kenyataannyabanyak masyarakat Wates berusaha sekuat tenaga untuk dapat menyelenggarakan acara mantu dengan sebaik-baiknya, sekalipun harus memerlukan biaya yang tidak sedikit, bahkan tergolong mahal bagi masyarakat petani yang lebih banyak memiliki harta dalam bentuk aset dan barang daripada uang tunai. ${ }^{8}$ Karena itulah, muncul tradisi nyumbang mantu dan sinoman sebagai salah satu solusi terhadap persolan tersebut di atas. Tradisi ini merupakan perwujudan dari pola sengkuyung barengbareng dan gotong royong, agar keluarga yang tidak memiliki modal apapun dapat menyelenggarakan mantu, karena disengkuyung bersamasama. Gotong royong dan tradisi nyengkuyung (mendorong) bersama-sama ini juga merupakan wujud dari sistem persaudaraan (brotherhood) dan solidaritas di masyarakat, di mana kesadaran masing-masing dalam hal ini

6 Robert Redfield, The Littel Community and Peasant Society and Culture, (Chicago and London: Phoenix Books, University of Chicago, 1963), 25-26.

7 James Dinandjaja, Antropologi Psikologi; Teori, Metode dan Sejarah Perkembangannya, (Jakarta: Rajawali Press, 1988), 46-47.

8 Wawancara dengan Sopiah 23-7-2016 
akan memperkuat nilai persaudaraan sosial dan persahabatan sosial di antara mereka.

Gotong royong dan solidaritas yang menjadi nilai masyarakat Wates adalah wajar, karena mereka adalah masyarakat petani desa, di mana umumnya hidup dan eksis karena mempertahankan sifat kegotongroyongan tradisional, yang berdasarkan solidaritas sosial masyarakat. Di samping itu, hubungan kekerabatan juga masih memegang peranan penting di sana. ${ }^{9}$ Fakta menunjukkan bahwa umumnya penduduk asli Wates memiliki hubungan kekerabatan baik dekat maupun jauh. Kekerabatan ini menjadi lebih kuat lagi dengan adanya pola perkawinan sekampung yang dilakukan oleh sebagian besar masyarakat di sana, yakni perkawinan di mana mempelai laki-laki dan wanita masih memiliki hubungan saudara jauh maupun dekat.

Sebagai contoh, di RW 3 Wates, itu hampir semua penduduknya, kecuali beberapa pendatang baru memiliki ikatan persaudaraan, sehingga apabila ada kejadian kematian, misalnya, mereka berbondong-bondong mengunjungi keluarganya. Selain karena alasan kewajiban sosial, hal itu sangat mungkin dilakukan karena juga alasan persaudaraan yang mengikat mereka. Hal demikian juga terjadi apabila ada peristiwa yang membahagiakan seperti acara mantu sebagai wujud dari kesadaran gotong royong dan solidaritas bersama. Dengan demikian, nilai gotong royong dan nyengkuyung bersama dalam kehidupan masyarakat Wates itu bertambah kokok, karena ditopang oleh kesadaran kekerabatan di samping kebutuhan akan hal itu.

Kegiatan gotong royong dan upaya nyengkuyung mantu bersamasama itu, salah satunya diwujudkan dalam tradisi 'nyumbang mantu'. Nyumbang mantu ini dilakukan oleh masyarakat Wates dengan berbagai bentuk, baik uang tunai maupun barang. Namun, umumnya mereka nyumbang mantu dengan barang, seperti beras lima kilo sampai beras sekintal, telur, gula, rokok, dan lain sebagainya. Barang-barang yang disumbangkan tersebut umumnya juga memiliki fungsi langsung dalam acara mantu tersebut. Beras, misalnya, merupakan bahan pokok paling banyak digunakan dalam acara mantu, karena digunakan untuk jamuan makan para tamu di samping digunakan pula untuk 'berkat' [buah tangan walimah yang diyakini memiliki nilai berkah bagi yang menerimanya] yang dibawa pulang para tamu sebagai oleh-oleh di rumah. Demikian juga, gula,

${ }_{9}$ Dinandjaja, Antropologi Psikologi; Teori, Metode dan Sejarah Perkembangannya, 47. 
jajanan, telur dan lainnya memiliki fungsi langsung dalam acara mantu itu. ${ }^{10}$

Besar kecilnya nyumbang mantu sangat tergantung dari kemampuan keluarga penyumbang itu sendiri dan juga ditentukan oleh struktur kedekatannya dengan keluarga yang mantu, baik dari sisi kekerabatan maupun persahabatan. Nyumbang mantu ini dilakukan baik oleh ibu rumah tangga maupun bapak rumah tangga. Ibu rumah tangga umumnya nyumbang dalam bentuk barang, sedangkan bapak rumah tangga kebanyakan nyumbang dengan uang tunai. Perbedaan bentuk barang yang disumbangkan oleh bapak rumah tangga dan ibu rumah tangga nampaknya ada kaitannya dengan posisi dan peran antara suami dan isteri yang umumnya dikenal dalam struktur masyarakat Jawa Islam. Suami berperan sebagai pencari nafkah di luar, sementara isteri berperan secara domestik dalam kehidupan rumah tangga, sehingga tepat manakala bapak rumah tangga nyumbang dengan uang tunai, sementara ibu rumah tangga nyumbang mantu dalam bentuk barang.

Peran-peran yang dimainkan para penyumbang dengan beragam tingkatan dan strukturnya itu hampir mirip dengan peran-peran dalam stuktural-fungsionalisme Durkheim, di mana masyarakat itu menjadi satu kesatuan yang di dalamnya terdapat bagian-bagian yang bisa dibedabedakan. Bagian-bagian dari sistem itu mempunyai fungsi-fungsi tersendiri dan interdependesi satu sama lain yang membuat sistem sosial menjadi seimbang.11 Demikian juga, nyumbang mantu ini pada prakteknya bertingkat. Berikut ini beberapa tingkatan nyumbang mantu di Wates;

Pertama, orang-orang yang memiliki ikatan persaudaraan dengan keluarga mantu, secara konvensional, biasanya dituntut menyumbang lebih banyak daripada keluarga lain yang tidak memiliki hubungan keluarga. Di samping memberikan sumbangan dalam bentuk barang atau uang tunai, mereka juga harus menyumbangkan tenaganya selama acara mantu itu berlangsung. Bentuk dan jumlah sumbangan yang diberikan mereka juga biasanya lebih baik kualitasnya dan lebih banyak kuantitasnya daripada yang lainnya. Sebagai contoh, bila umumnya orang nyumbang lima kilo atau sepuluh kilo beras, maka mereka dalam tradisinya dituntut nyumbang beras $50 \mathrm{~kg}$ atau $100 \mathrm{~kg} .{ }^{12}$ Dedikasi itulah yang dipandang oleh mereka sebagai perwujudan dari pengakuan atas persaudaraannya (brotherhood).

\footnotetext{
10 Wawancara dengan H. Soali, 12-2016

11 George, Ritzer, dan Douglas J. Goodman, Teori Sosiologi Modern, (Jakarta: Kencana, 2007), 45.

12 Wawancara dengan Sopiah 23-7-2016
} 
Kedua, orang-orang yang memiliki ikatan pertemanan atau persahabatan dengan keluarga mantu, secara reguler, dituntut memberikan sumbangan yang cukup pantas atau cukup baik, sekalipun tidak menutup kemungkinan ada yang nyumbang melebihi apa yang diberikan saudaranya. Hal ini sebagai cerminan, perwujudan sekaligus bukti dari nilai persahabatan di antara mereka. Sahabat yang baik tentu akan senang memberikan banyak pertolongan kepada temannya sebagai simbol kesetiakawanan. Sebaliknya, sahabat yang kurang baik tidak akan banyak membantu temannya sekalipun di saat ia membutuhkannya. ${ }^{13}$

Ketiga, orang-orang yang tidak secara khusus memiliki ikatan persaudaraan maupun persahabatan dengan keluarga mantu, umumnya, memberikan sumbangan sekedarnya, kecuali mereka yang menambah ikatan persaudaraan atau ingin menyumbang dalam pengertian investasi untuk acara mantu yang kelak ia selenggarakan. Orang yang demikian ini biasanya akan memberikan sumbangan yang sepadan atau bahkan melebihi apa yang diberikan seorang saudara kepada keluarga mantu. ${ }^{14}$

Kualitas dan bentuk sumbangan juga dapat beragam sesuai dengan perbedaan status orang yang yang 'menyumbang' dan status orang yang disumbang. Sekalipun, norma idealnya mengajarkan bahwa orang yang lebih miskin harus disumbang lebih banyak daripada orang yang kaya raya, namun kenyataan faktualnya tidak demikian. Banyak orang bertindak secara interaksi-simbolik, di mana kualitas sumbangan akan ditentukan oleh status penyumbang dan juga status orang yang disumbang itu sendiri. Seorang yang berstatus terhormat atau dikenal kaya cenderung menyumbang dengan nilai sepadan dengan status kekayaannya atau kehormatannya, demikian juga subjek mantu yang memiliki status lebih kaya atau lebih terhormat cenderung akan disumbang dengan nilai yang sepadan dengan statusnya tersebut. Karena, sesungguhnya sumbangan itu sendiri merupakan simbol yang bermakna dalam proses interaksi dan sosialisasi di masyarakat. Menurut Mead, manusia itu memiliki dirinya sendiri, yakni ia mampu menjadi subjek sekaligus objek bagi dirinya sendiri. Dalam bersosialisasi ia dapat memainkan peran bagi orang yang dianggap penting, memerankan peran dan memahami peran orang lain dalam kelompoknya, serta dapat berperan sesuai dengan harapan, kebiasaan dan nilai-nilai umum yang berlaku dalam masyarakatnya. ${ }^{15}$

13 Wawancara dengan Sopiah 23-7-2016

14 Wawancara dengan Sopiah 23-7-2016

15 Doyle Paul, Johnson, Teori Sosiologi Klasik dan Modern, (Terj), (Jakarta: Gramedia Pustaka Utama, 1990), 21-23; Ambo, Upe, Tradisi Aliran dalam Sosiologi, (Jakarta: Raja Grafindo Persada, 2010), 226. 
Dorongan nyumbang mantu dalam masyarakat Wates ini berjalan secara otomatis, tanpa harus ada undangan khusus. Masyarakat nampaknya telah memiliki kesadaran otomatis bila ada keluarga mantu, mereka akan berbondong-bondong mendatanginya. Hal itu bahkan menjadi simbol seduluran [persaudaraan] di antara mereka. Nyumbang mantu ini nampaknya telah disadarai oleh masyarakat Wates -meminjam istilah teori resiprositas- sebagai kewajiban sosial, sekalipun disertai dengan harapan-harapan lain seperti prestise sosial, kewibawaan sosial ${ }^{16}$, dan berkah.

Dengan demikian, dapat dipahami bahwa orang yang tidak melakukan nyumbang mantu tersebut akan disadari, secara konvensional, sebagai orang yang tidak menunaikan kewajiban sosialnya dan laksana orang lain yang tidak ingin nyedulur, dan akibatnya ia bisa tersisolasi dalam masyarakat, yang akan mendapatkan perlakuan berbeda, dan tidak akan disengkuyung acara mantunya oleh mereka. Perlakuan berbeda itu bisa berwujud bahwa mereka tidak akan banyak diundang dalam berbagai acara di masyarakat, atau masyarakat tidak akan mendatangi dan nyengkuyung acara hajatan yang dilakukannya. Karena, dalam resiprositas umum ini tidak ada hukum yang secara ketat mengontrol seseorang untuk memberi atau mengembalikan. Dorongan moral sajalah yang mengontrol dan menyebabkan pribadi-pribadi untuk menerima resiprositas umum sebagai kebenaran yang tidak boleh dilanggar. Karena, orang yang melanggar resiprositas ini mungkin mendapat tekanan moral sosial dari "masyarakat" atau "kelompok" apapun bentuknya yang dapat menurunkan martabat sosialnya.

Nyumbang mantu yang dilakukan oleh mereka akan selalu diingatingat oleh keluarga yang berhajat. Bahkan, sebagian besar keluarga mantu akan mencatat secara detail bentuk dan jumlah barang yang disumbangkan seseorang kepada mereka. Harapannya, mereka nanti akan membalasnya minimal setimpal kepada masing-masing orang ketika gilirannya memiliki acara mantu. Balasan nyumbang setimpal seakan menjadi kewajiban konvensional yang telah mereka sepakati. Artinya, adalah aib manakala seseorang nyumbang mantu lebih kecil jumlahnya daripada sumbangan yang didapatkannya. Ada kesepakatan tidak tertulis yang dipahami bersama bahwa nyumbang itu laksana ngutangi atau semacam arisan, yang masing-masing memiliki kewajiban dan haknya. ${ }^{17}$ Maka orang yang pernah disumbang, tetapi tidak mengembalikan sumbangannya itu, berarti pula ia

\footnotetext{
16 Haviland, Antropologi, 50.

17 Wawancara dengan H. Isa, 18-5-2016.
} 
tidak menunaikan hutangnya. Karenanya, hal itu akan menjadi cacat tersendiri dalam masyarakat. Karena itu, mereka berpandangan bahwa lebih baik nyumbang lebih daripada nyumbang kurang dari sumbangan yang didapatkannya, karena hal itu akan mengangkat prestise sosial di kalangan mereka.

Tradisi nyumbang mantu di Wates, dari sudut karakteristiknya, merupakan bagian dari resiprositas. Karl Polanyi, sebagaimana dikutip Haviland, mengklasifikasikan resiprositas dalam sistem budaya distribusi barang, di samping redistribusi dan pertukaran pasar. ${ }^{18}$ Resiprositas mengacu pada suatu transaksi antar dua pihak di mana barang dan jasa yang kurang lebih sama nilainya dipertukarkan. Hal ini dapat meliputi pemberian hadiah. Yang menjadi motif utama perilaku ini adalah memenuhi kewajiban sosial dan barangkali bersama-sama dengan itu sedikit menambah kewibawaan sosial. ${ }^{19}$ Jadi, dalam resiprositas ini selalu ada harapan-harapan pemberi hadiah. Harapan-harapan tersebut dapat berupa prestise sosial seperti penghargaan, kemuliaan, kewibawaan, popularitas, sanjungan, dan berkah.

Dari uraian di atas, dapat diketahui bahwa tanpa adanya hubungan simetris antar kelompok atau antar individu, maka resiprositas cenderung tidak akan berlangsung. Hubungan simetris ini adalah hubungan sosial, di mana masing-masing pihak menempatkan diri dalam kedudukan dan peranan yang sama ketika proses pertukaran berlangsung. ${ }^{20}$ Syarat lain terjadinya resiprositas adalah adanya hubungan personil di antara masyarakat. Pola hubungan ini terutama terjadi di dalam komunitas kecil di mana anggota-anggotanya menempati lapangan hidup yang sama. Dalam komunitas kecil itu kontrol sosial sangat kuat dan hubungan sosial yang intensif mendorong orang untuk berbuat untuk mematuhi adat kebiasaan. Sebaliknya, hubungan impersonal tidak bisa menjamin berlakunya resiprositas, karena interaksi antar pelaku kerja sama resiprositas sangat rendah. ${ }^{21} \mathrm{Hal}$ inilah tentu yang menjadi alasan Haviland menyebutkan bahwa seseorang yang melakukan aktivitas resiprositas didorong oleh keinginan untuk memenuhi kewajiban sosial, di samping ada harapanharapan lainnya.

18 E. Edward LeClair dkk (ed.), Economic Antropology Reading in Theory and Analysis, (New York, 1986), 122-143.

${ }^{19}$ A. William Haviland, Antropologi, (Jakarta: Airlangga, Jilid 2, 1993), 50.

$20 \mathrm{http}$ :antropnesia.blogspot.com/2012/02/teori-resiprositas.html

21 http:antropnesia.blogspot.com/2012/02/teori-resiprositas.html 
Kenyataan ini kemudian diperkuat dengan pendapat Sahlins, dimana dirinya membagi resiprositas menjadi tiga macam; yaitu:.22

Pertama, resiprositas umum (generalized reciprocity) dapat didefinisikan sebagai resiprositas di mana nilai atas apa yang diberikan tidak diperhitungkan dan juga waktu pemberian imbalan tidak ditentukan. ${ }^{23}$ Kedua, resiprositas berimbang (balanced reciprocity) merupakan proses resiprositas bukan jangka panjang, melainkan proses di mana pemberian dan penerimaannya, dan juga waktunya lebih spesifik. ${ }^{24}$ Ketiga, resiprositas negatif (negative reciprocity) merupakan bentuk pertukaran di mana orang yang memberi berusaha mendapatkan keuntungan dari tukar menukar itu. Pihak-pihak yang terlibat memiliki kepentingan yang saling berlawanan. Biasanya mereka memiliki tempat kediaman yang saling berjauhan dan tidak memiliki hubungan kedekatan. Bentuk resiprositas negatif yang ekstrim adalah untuk mengambil sesuatu secara paksa. Bentuk-bentuk lain yang tidak begitu ekstrim adalah menggunakan tipuan atau muslihat. ${ }^{25}$

Menurut hemat peneliti, resiprositas masyarakat Wates lebih pada hal yang umum, ditentukan oleh konsepsi kekerabatan secara kultural. Namun, ada juga sebagaian kecil masyarakat yang masuk dalam kategori resiprositas berimbang, seperti adanya kesadaran untuk mengembalikan sumbangan minimal setara nilainya dengan sumbangan yang pernah diterimanya. Haviland menyebutkan bahwa dalam resiprositas tersebut, memberi, menerima dan berbagi barang adalah suatu bentuk jaminan sosial atau asuransi. Sebuah keluarga membantu orang-orang lain apabila mampu, dan dapat berharap akan menerima sesuatu dari orang-orang lain tersebut pada saat ia membutuhkannya. ${ }^{26}$

Tradisi nyumbang mantu itu juga sekaligus menegaskan teori Homans bahwa umumnya individu atau kelompok berinteraksi dan berasosiasi satu sama lain, karena keinginan untuk mendapatkan ganjaran sosial (social reward). ${ }^{27}$ Alasan mereka melakukan hal itu adalah ketertarikan mereka pada pertukaran, karena mengharapkan ganjaran baik ekstrinsik maupun intrinsik seperti sumbangan balik [jaminan sosial mantu atau 'arisan'] dan prestise sosial yang didapatnya. Pertukaran

22 Marshall Sahlins, Stone Age Economics, (New York: Aldine de Gruyter, 1972), 193195.

${ }^{23}$ Haviland, Antropologi, 50.

${ }^{24}$ Haviland, Antropologi, 51.

25 Haviland, Antropologi, 52.

26 Haviland, , Antropologi, 51.

27 Margaret M. Poloma, Sosiologi Kontemporer, (Jakarta: PT Raja Grafindo Persada, 2000), 84 . 
tersebut dapat terjadi kapan saja dan di mana saja, bukan saja pada ranah jual beli, tetapi juga dalam hubungan persahabatan dan persaudaraan, ${ }^{28}$ seperti dalam tradisi nyumbang mantu tersebut.

Kesadaran bahwa memberi dan menerima sebagai kewajiban sosial, secara tidak langsung, menyebabkan mereka menyadari bahwa nyumbang mantu itu bagaikan "ngutangi" tanpa bunga [jaminan sosial], yang akan dipenuhi hutangnya itu ketika penyumbang itu pada gilirannya memiliki acara mantu sendiri. Semakin banyak nyumbang, maka semakin banyak sumbangan yang akan dikembalikan kepadanya, sehingga nyumbang itu layaknya nabung untuk acara mantu di masa yang akan datang. Alasan inilah barangkali yang melatarbelakangi masyarakat Wates umumnya berani menyelenggarakan mantu secara besar-besaran, sekalipun keluarga yang bersangkutan nampak 'tidak kaya' secara ekonomi, karena kalkulasi mereka bukan berdasarkan modal tunai yang dimilikinya saat itu, tapi berdasarkan kalkulasi pada seberapa banyak sumbangan yang ia keluarkan kepada orang lain, yang akan dikembalikan kepadanya pada acara mantu tersebut.

\section{Evolusi dalam Tradisi Nyumbang Mantu}

Tradisi nyumbang mantu laksana arisan ini, menurut $H$. Isa, merupakan tradisi yang telah berkembang sekitar 20 tahun terakhir hingga sekarang, karena sebelumnya tradisi nyumbang mantu itu lebih sederhana. Nyumbang mantu waktu itu masih bermakna shadaqoh dan jumlahnya juga sederhana sesuai dengan kemampuan masing-masing. Acara mantu yang diselenggarakan juga bersifat sederhana, seperti cukup akad dan walimah atau slametan, sehingga biaya yang dibutuhkan untuk acara mantu tersebut tidak terlalu banyak..$^{29}$

Sementara tradisi mantu yang belakangan tersebut tidak saja meliputi akad dan walimah atau slametan saja, melainkan juga ada acara pengajian dan hiburan qasidah (simbol) di malam hari bagi keluarga religius (santri -meminjam istilah Clifford Geertz), atau acara dangdutan seharian (simbol) bagi orang abangan, dan atau acara dangdutan di siang hari dan pengajian serta qasidah di malam hari bagi orang yang berada di antara religius dan abangan. Penambahan acara dalam tradisi mantu itu tentunya menambah kost yang harus dikeluarkan oleh pihak yang

28 Tom R. Burns, Manusia, Keputusan dan Masyarakat, (Jakarta: PT Pradnya Paramita, Jakarta, 1987), 87.

29 Wawancara dengan H. Isa 18-5-2016. 
bersangkutan, maka solusi konvensionalnya adalah nyumbang mantu yang bermakna arisan. Istilah 'nyumbang' mengesankan shodaqoh, tapi hakekatnya 'arisan', terutama bagi mereka yang jumlah sumbangannya melebihi batas minimal sumbangan umum. Jumlah sumbangan yang termasuk kategori arisan misalnya adalah sumbangn seharga lima puluh ribu rupiah ke atas baik dalam bentuk uang tunai maupun barang. ${ }^{30}$

Evolusi nyumbang mantu ini nampaknya selain karena menjadi solusi bagi persoalan semakin bertambahnya acara dalam tradisi mantu dan bertambahnya biaya tersebut, juga sangat dimungkinkan sebagai akibat dari proses akulturasi budaya masyarakat Wates dengan masyarakat lainnya seperti masyarakat kota, dan kepentingan dakwah Islam, terutama dalam pola mantu di kalangan masyarakat santri atau antara santri dan abangan. Karena, sebelum tahun 90-an desa Wates merupakan desa pinggiran kota yang cukup terisolasi dari akses kemajuan dan modernisme di perkotaan karena buruknya infra struktur yang ada di sana. Selain itu, sejak tahun 90-an banyak bermunculan sarjana agama dari kalangan pesantren, ilmu dakwah dan ilmu pendidikan yang diduga kuat berpengaruh besar bagi terjadinya transformasi acara mantu dari slametan sederhana menjadi walimah yang disertai acara pengajian mantenan dan hiburan religius. ${ }^{31}$ Transformasi ini sangat erat kaitannya dengan kepentingan dakwah Islam terhadap masyarakat agar mereka semakin mengetahui dan menyadar nilai-nilai Islam yang harus diamalkan dalam kehidupan. Transformasi tradisi inilah yang juga disebut sebagai akulturasi Islam dan Jawa, sebagai jalan untuk menguatkan nilai-nilai Islami dalam masyarakat. Karena, nilai-nilai apapu yang diyakini masyarakat itu hanya akan bertahan lama apabila telah menjadi tradisi dan budaya bagi mereka.

Secara historis, tradisi nyumbang mantu itu sudah ada sejak zaman dulu hingga saat ini, meskipun tradisi ini sedikit mengalami perubahan sesuai dengan alur perkembangan zaman. Dalam masyarakat agraris dahulu, menyumbang itu tidak harus berujud uang, tetapi bisa berujud barang kebutuhan sehari-hari, seperti beras, kelapa, beras ketan, jagung, kayu, kentang, gula, teh, ayam, kambing, dan sebagainya sesuai dengan barang berharga yang dimiliki oleh masyarakat bersangkutan. Berbeda dengan masyarakat petani, nyumbang mantu dalam masyarakat industri di perkotaan tetap eksis dan dipelihara dengan beberapa modifikasi di dalamnya.

\footnotetext{
30 Wawancara dengan H. Isa 18-5-2016

31 Wawancara dengan H. Mansur 19-5-2016.
} 
Menurut pengamatan penulis, modifikasi nyumbang mantu dari masyarakat petani oleh masyarakat industri terlihat misalnya dalam perubahan istilah, bentuk nilai yang disumbangkan dan mekanisme nyumbang yang dilakukan. Dalam masyarakat petani di Wates, nyumbang mantu sering disebut dengan istilah pinaraan atau jagong. Pinaraan yang berarti berkunjung dan duduk sambil menikmati hidangan dengan santai dan sesekali tuan rumah yang memiliki hajatan mantu menyambutnya dan berkomunikasi sebaik mungkin, yang diakhiri dengan pamitan orang yang nyumbang dan diberi cindera mata berupa berkat sebagai tanda terima kasih atas kunjungan dan do'anya.

Sementara itu, dalam masyarakat industri nyumbang mantu disebut dengan istilah resepsi yang berasal dari bahasa inggris 'reception' yang berarti penyambutan atau perjamuan. Kedua kata itu tentu memiliki makna konotasi yang sedikit berbeda. Bila pinaraan itu lebih banyak aspek berkumpul dan komunikasinya, karena kata itu bermakna untuk berkunjung ke rumah orang yang mantu, duduk, menikmati hidangan yang disediakan sambil berkomunikasi dan bersilaturrahmi dengan tuan rumah dan sesama tamu penyumbang; maka resepsi itu dalam prakteknya lebih fokus pada perjamuan makanan, mengucapkan selamat pada tuan rumah dan selesai pulang. Sedangkan barang yang disumbangkan dalam masyarakt perkotaan umumnya berbentuk uang tunai atau kado yang berisi barang berharga tertentu yang dianggapnya lebih ringkas.

\section{Konsep Dakwah dalam Tradisi Mantu}

Resiprositas sering dinilai sebagai bentuk pertukaran yang manusiawi jika dibandingkan dengan pertukaran pasar. Prinsip kekeluargaan dan kesetiakawanan merupakan bukti bahwa resiprositas lebih manusiawi daripada pertukaran pasar. Ketika segala sesuatu telah dinilai dengan uang, maka segala barang juga akan dihargai dengan uang. Demikian juga, ketika budaya kapitalisme melakukan penetrasi ke dalam masyarakat Jawa, maka tradisi mantu ikut dipengaruhi oleh faham tersebut. Pengaruh kapitalisme tersebut nampak misalnya dalam bentuk bahwa segala pernak pernik mantu sudah banyak diserahkan ke orang lain dengan model jual-beli. Makanan sudah diserahkan ke katering, demikian pula pelayanan, persewaan pecah-belah, meja kursi, dekorasi, tarub, busana, tempat resepsi, MC, dan lain sebagainya.

Konsekuensinya, tradisi rewang (membantu memasak bagi ibu-ibu) dan membantu orang yang punya hajat sudah semakin berkurang. Rewang menjadi kehilangan makna subtansinya, karena rewang hanya sekedar 
untuk pantas-pantas saja, seperti jagongan mengobrol untuk kebersamaan saja. Sementara akitivitas membantu yang sebenarnya dalam makna rewang itu sudah tidak lagi maksimal, karena semuanya sudah dijualbelikan. Bahkan ada sebagian orang punya hajat yang kapitalistik murni, yakni membisniskan acara mantu. Ketika punya hajat, ia telah menghitung detail anggarannya dan pendapatan sumbangan, sehingga dengan kalkulasi cerdas hasil akhir yang diperolehnya adalah untung besar. Kapitalisasi mantu ini pada gilirannya membuat distorsi makna nyumbang mantu yang sesungguhnya, yakni brotherhood dan solidarity. Inilah yang dalam teori resiprositas, barangkali disebut sebagai resiprositas negatif (negative reciprocity), yakni pertukaran di mana orang yang memberi hadiah atau pihak yang mantu berusaha mendapatkan keuntungan dari tukar menukar itu. Pihak-pihak yang terlibat memiliki kepentingan yang saling berlawanan. ${ }^{32}$

Padahal sebelumnya tradisi menyumbang itu dilakukan untuk mengajarkan filosofi hidup bersama-sama dan bertujuan meringankan kesulitan pemilik hajat. Tradisi meyumbang pada dasarnya dilakukan atas gotong royong dan solidaritas karena memang untuk meringankan pemilik hajat. Seperti arti kata mantu sendiri, yaitu bermakna 'sing dieman-eman metu', yakni segala yang disayangi dan dimiliki harus dikeluarkan atau diberikan, berupa anak, biaya, tenaga, dan pemikiran. Orang yang memiliki hajatan dahulu dengan ikhlas mengeluarkan segala yang dimiliki tanpa berkeinginan balik modal dan jauh dari keinginan jual-beli, untung dan rugi. Demikian juga, para pemberi sumbangan juga melakukannya karena kesadaran sosial mengenai pentingnya saling tolong menolong di antara mereka demi persaudaraan dan persahabatan di antara mereka.

Hal-hal di atas terkait dengan nilai sosiologis-antropologis yang dapat diambil dari kesimpulan kajian nyumbang mantu. Namun, perlu diingat bahwa selain resiprositas hubungan antara masyarakat satu dengan lainnya, terdapat juga akulturasi budaya Jawa dan Islam sebagai nilai yang disandarkan pada acara tersebut. Beberapa nilai yang terkadung dalam kajian materi dakwah antara lain adalah konsep bertetangga dalam Islam. Beberapa hal hak bertetangga antara lain; 1) memuliakan dan berbuat baik, 2) meringankan beban dan kesulitan tetangga, 3) menutup aib, 4) tidak mengganggu, 5) Sabar menghadapi ganggua tetangga, 6) tidak membiarkannya dalam kekurangan dan kelaparan, 7) mengutamakan tentangga yang paling dekat. ${ }^{33}$

32 Haviland, Antropologi, 52.

33 Syaikh Ali Khasan al-Halabi, Huququl Jar fil Shahibis sunnah Wal Atsar, (Beirut: Dar Ibn Hazm, 1985) hlm 6-10 
Melihat beberapa konsepsi Islam tentang bertetangga dan pemenuhan hak dan kewajibannya, maka ini merupakan tuntunan yang dapat diakselerasikan dengan tradisi Nyumbang Mantu. Beberapa ide dasar yang ada dalam nyumbang mantu menurut peneliti identik dengan beberapa hal yang terkandung dalam nilai Islam. Untuk itu yang terpenting untuk digelorakan adalah bagaimana membingkai tradisi nyumbang mantu sesuai dengan nlai tersebut. Penelitian lebih lanjut untuk mengupas hal tersebut kiranya menjadi topik yang perlu untuk dilihat dengan pendekatan antropologi budaya dan agama.

\section{E. Kesimpulan}

Ada beberapa kesimpulan yang dapat ditarik dari kajian tersebut di atas. Pertama, acara mantu dalam tradisi masyarakat Jawa Wates Ngaliyan Semarang berbentuk 'mantu sunatan' dan 'mantu ngantenan'. Keberadaannya memiliki arti yang penting dalam pandangan masyarakat Wates. Signifikansi mantu tersebut di kalangan mereka telah menjadi tuntutan kultural, sekaligus tuntunan agama tentang kedua praktek. Secara kultural dapat didekati dengan acuan teori resiprositas, sementara sesuai antropologi dakwah bahwa nilai agama (Islam) menjadi sangat kental sekali, walaupun terjadi akulturasi budaya, antara Islam dan Jawa.

Kedua, tradisi nyumbang mantu merupakan perwujudan dari pola dukung bersama-sama dalam masyarakat dan gotong royong. Bagi masyarakat yang tidak mempunyai kekuatan dalam menyelenggarakan acara ini akan didorong dan dibantu oleh masyarakat sekitar. Gotong royong dan tradisi nyengkuyung bersama-sama ini juga merupakan wujud dari sistem persaudaraan (brotherhood) dan solidaritas di masyarakat, di mana kesadaran masing-masing dalam hal ini akan memperkuat nilai persaudaraan sosial dan persahabatan sosial di antara mereka. Hal ini sekali lagi menguatkan teori resiprositas yang ada.

Ketiga, Evolusi tradisi nyumbang mantu di Wates merupakan sebuah keniscayaan, disini dapat dikatakan bahwa dakwah menjadi penting untuk dilakukan dalam mengisi perubahan dan sistematika upacara nyumbang mantu yang dilaksanakan oleh masyarakat. Dorongan moral dan agama dapat dijadikan sebagai sebuah upaya untuk meningkatkan pentingnya kegiatan nyumbang mantu, disamping melestarikan nilai yang telah ada.

Keempat, transformasi mantu dari slametan sederhana menjadi walimah beserta pengajian mantenan dan hiburan religus, terutama pada masyarakat "santri" sesungguhnya merupakan bentuk dari akulturasi Jawa dan Islam. Akulturasi ini terjadi sebagai proses penguatan nilai-nilai Islam 
dalam masyarakat. Karena, nilai-nilai tertentu yang diyakani masyarakat hanya akan bertahan lama ketika tumbuh dan berkembang menjadi budaya dalam masyarakat. Selain kepentingan dakwah Islam tersebut, tradisi nyumbang mantu itu juga mencerminkan nilai "ta'āwun" dalam Islam yang terbingkai dalam semangat gotong-royong dan sengkuyung bersama. 


\section{DAFTAR PUSTAKA}

Abu Daud, al-Imam, Sunan Abu Dawud, Dar al-Fikr, Beirut-Libanon, t.t.

Al-Mundziri, Zakiyuddin Abdul Adzim, al-Targhib wa al-Targhib min alHadits al-Syarif, Dar al-Fikr, Beirut-Libanon, 2010

Al-Halabi, Huququl Jar fil Shahibis sunnah Wal Atsar, Beirut: Dar Ibn Hazm, 1985

Al-Naisaburi, Al-Hakim, al-Mustadrak, Dar al-Fikr, Beirut-Libanon, t.t.

Burns, Tom R., Manusia Keputusn dan Masyarakat, PT Pradnya Paramita, Jakarta, 1987.

Dinandjaja, James, Antropologi Psikologi; Teori, Metode dan Sejarah Perkembangannya, Rajawali Press, Jakarta, 1988

Haviland, A, William, Antropologi, Airlangga, Jakarta, Jilid 2, 1993

http:antropnesia.blogspot.com/2012/02/teori-resiprositas.html

http:en.wikipedia.org/wiki/Reciprocity_(cultural_anthropology)

Johnson, Doyle Paul, Teori Sosiologi Klasik dan Modern, Terj. Robert M.Z., Gramedia Pustaka Utama, Jakarta, 1990

LeClair, E. Edward dkk (ed.), Economic Antropology Reading in Theory and Analysis, New York, 1986

Poloma, Margaret M., Sosiologi Kontemporer, PT Raja Grafindo Persada, Jakarta, 2000.

Redfield, Robert, The Littel Community and Peasant Society and Culture, Chicago and London, Phoenix Books, University of Chicago, 1963

Ritzer, George dan Douglas J. Goodman, Teori Sosiologi Modern, Cet. Ke-4, Kencana, Jakarta, 2007

Sahlins, Marshall, Stone Age Economics, New York: Aldine de Gruyter, 1972

Soekanto, Soerjono, Pengantar Sosiologi, Rajawali Press, Jakarta, 1990

Turner, H., Jonathan dan Alexandra Maryansky, Fungsionalism, (terj. Anwar Effend dkk.), Pustaka Pelajar, Yogyakarta, 2010

Upe, Ambo, Tradisi Aliran dalam Sosiologi, Raja Grafindo Persada, Jakarta, 2010 